\title{
Onenigheid over een Doopvraag \\ De Gevolgen van Twee Incidenten in het Amsterdam van 1613 voor de Vormgeving van de Remonstrantse en Contraremonstrantse Doopliturgie
}

Klaas-Willem de Jong en Wouter Kroese ${ }^{1}$

\section{Abstract}

In this essay, the authors use new primary sources to reconstruct which baptism questions were asked during two services held in Amsterdam in 1613. These services, which were taken by, amongst others, the Reformed ministers P. Plancius and G. van der Heyden and in which the later Remonstrant foremen J. Wtenbogaert and S. Episcopius acted as godparents, caused great turmoil. Research of the various editions of baptismal liturgy reveals three basic types of the second baptism question. Primary and secondary literature have overlooked the significance of one of these types in the Amsterdam services. Wtenbogaert and Episcopius, but especially the latter, were not aware of the existence of all three types and felt misled since they did not want to subscribe to the doctrine taught from the Amsterdam pulpits by affirming the questions posed. The authors outline the impact of the incidents on the format of both later Reformed and later Remonstrant baptismal liturgy.

\section{Keywords}

Amsterdam, doopliturgie, doopvragen, remonstranten, contraremonstranten

De wordingsgeschiedenis van de vragen in het klassieke gereformeerde doopformulier is wel gekwalificeerd als een 'lijdensgeschiedenis'. ${ }^{2}$ Dat geldt wel in het bijzonder voor twee met elkaar samenhan-

1) Beide auteurs tekenen voor dit artikel en de daarin opgenomen conclusies. Klaas-Willem de Jong schreef de hoofdlijn en bestudeerde in het bijzonder de incidenten in 1613, terwijl Wouter Kroese met name zijn kennis inbracht aangaande de verschillende edities van het doopformulier.

2) B. Wielenga, Ons doopsformulier (Kampen: J.H. Kok, 1906), 15 (Wielenga cursiveert 'lijdens'). Vgl. Fr. de Jong en K.W. de Jong, "Van forme naar formulier. Het ontstaan en de ontwikkeling van het klassieke gereformeerde doopformulier in de Nederlandse Reformatie," Jaarboek voor Liturgie-onderzoek 14 (1998): 7-59, m.n. 8, 34-44. Het onderzoek waarvan wij in dit artikel in het Yearbook verslag doen staat in het kader van het project dat Klaas-Willem de Jong eerder presenteerde: K.W. de Jong, "The Dynamics of the Classical Reformed Liturgy in the Netherlands: Its Texts and their History. Presentation of a Project," Yearbook for Ritual and Liturgical Studies 34 (2018): 1-13. 
gende momenten in deze wordingsgeschiedenis die wij in dit artikel aan een nader onderzoek willen onderwerpen. In beide gevallen betreft het remonstrantse voormannen die in 1619 ten gevolge van de besluiten van de synode van Dordrecht gedwongen werden de gereformeerde kerk te verlaten. Het eerste incident vond plaats op donderdag 14 februari 1613, toen Johannes Wtenbogaert (1557-1644) in de Amsterdamse Oude Kerk optrad als getuige bij de doop van Johannis, de zoon van zijn stiefdochter Joanna aux Brebies. ${ }^{3}$ Het tweede incident geschiedde eveneens in Amsterdam, op dinsdag 2 april 1613, toen Simon Episcopius (1583-1643) in de Nieuwe Kerk als getuige aanwezig was bij Giertje, de dochter van zijn broer Jan. ${ }^{4}$ Beide incidenten behoren tot de vele die het voorspel vormen op de Dordtse synode. Zij hebben in het bijzonder vanwege de bejegening die Wtenbogaert en Episcopius tijdens en na de dienst ten deel viel tot aan het Engelse hof beroering gewekt, maar dat kan hier verder buiten beschouwing blijven. ${ }^{5}$ In de literatuur zijn deze gebeurtenissen zonder weging van de achterliggende bronnen met name beschreven aan de hand van enkele 17 e-eeuwse kerkhistorische publicaties. ${ }^{6}$ R.B. Evenhuis doet dat bijvoorbeeld in zijn bekende standaardwerk Ook dat was Amsterdam, al maakt hij

3) Gemeentearchief Amsterdam (GAA), DTB Amsterdam, Oude Kerk, 14 februari 1613. Wtenbogaerts aanwezigheid als getuige is opgetekend. In dit artikel is voor de spelling van de 16e-17e-eeuwse namen in beginsel gekozen voor de primaire weergave in het standaardwerk Biografisch Lexicon voor de Geschiedenis van het Nederlands Protestantisme (BLGNP). Voor Wtenbogaert zie verder BLGNP II, 464-68.

4) GAA, DTB Amsterdam, Nieuwe Kerk, 2 april 1613. Episcopius staat genoteerd als getuige (zie verder voor hem BLGNP II, 191-95). De doop werd bediend door ds. Roelof Petri van Niedek (over hem: NNBW 5), het houden van de preek en het stellen van de vragen echter was in handen van Gaspar van der Heyden (zie verderop in dit artikel). We hebben niet kunnen achterhalen of Wtenbogaert en Episcopius al eerder in Amsterdam getuige waren geweest bij een doop. Wel was elk van hen eerder in aanvaring gekomen met Amsterdamse predikanten of de Amsterdamse kerkenraad. Zie voor Episcopius meer specifiek: F.L. Rutgers, Het kerkverband der Nederlandsche Gereformeerde Kerken, gelijk dat gekend wordt uit de handelingen van den Amsterdamschen Kerkeraad in den aanvang der 17e eeuw [... ] (Amsterdam: J.H. Kruyt, 1882), 40, 99-102.

5) We beperken ons hier tot de verwijzing naar een aantal brieven die ook het bredere kader schetsen: S.P. Haak en A.J. Veenendaal, eds., Johan van Oldenbarnevelt. Bescheiden betreffende zijn staatkundig beleid en zijn familie 2 (RGP 108) ('s-Gravenhage: Martinus Nijhoff, 1962), 542-49 (briefnrs. 429-34); P.C. Molhuysen, ed., Briefwisseling van Hugo Grotius I ('s-Gravenhage: Martinus Nijhoff, 1928), 248-51 (briefnr. 272, vgl. ook 273). Ook de literatuur in de volgende noot doet verslag van deze verwikkelingen.

6) Het betreft J. Wtenbogaert, De Kerkelicke Historie, Vervatende verscheyden Gededenckwaerdige Saecken, Inde Christenheyt voorgevallen, Van Het Jaer Vierhondert af, tot in het Jaer Sestienhondert ende Negentien. Voornamentlick in dese Geunieerde Provincien ([Rotterdam:] 1646), 609-12; J. Trigland, Kerckelycke Geschiedenissen [... ] (Leiden: Adriaen Wyngaerden: 1650), 658-64; G. Brandt, Historie der Reformatie [... ] II (Jan Rieuwertsz, Hendrik en Dirk Boom, 1674), 216-25. 
ook gebruik van de kerkenraadsnotulen. ${ }^{7}$ In dit artikel pogen wij met behulp van een ruimere keuze van bronnen op het spoor te komen welke vragen er precies gesteld zijn in deze twee doopdiensten, in het bijzonder met betrekking tot de tweede doopvraag die de aanleiding vormde voor de beroering. Het belang daarvan is tweeërlei. In de eerste plaats verheldert dit de latere remonstrantse praktijk inzake de doopvragen. In de tweede plaats, zo zal blijken, helpt dit de formulering van de tweede doopvraag zoals die uiteindelijk gemeengoed werd in de gereformeerde kerken, te verklaren. Hoewel aan remonstrantse zijde ook bezwaren bestonden tegen de eerste en de derde doopvraag, is de waardering van de tweede doopvraag exemplarisch voor die van alle doopvragen. ${ }^{8}$

We beginnen met een korte schets van de ontwikkeling van de tweede doopvraag sinds Dathenus die in 1566 voor het eerst publiceerde. Vervolgens introduceren we de gebruikte bronnen. Daarna stellen we op grond van een analyse van deze bronnen vast welke bewoordingen zijn gebruikt, alsmede hoe een en ander vervolgens heeft doorgewerkt aan zowel contraremonstrantse als remonstrantse zijde. We eindigen met enkele conclusies.

\section{De voorgeschiedenis van de tweede doopvraag}

Het doopformulier zoals Petrus Dathenus dat in 1566 achter zijn psalmberijming uitgaf, kent drie vragen. De eerste heeft betrekking op de aanwezigheid van de overtuiging dat het kind gedoopt behoort te worden. De tweede richt zich op het onderliggende geloof van de ouders. Een enkelvoudig 'lae wy' volgt in deze uitgave alleen op de derde vraag, waarin de ouders bevraagd worden op hun bereidheid hun kind 'daerin', in 'dese leere', op te voeden. Dathenus formuleert de tweede vraag als volgt:

Ten anderen, of ghy dese leere, die hier gheleert wert, ende voorder, in 't oude en de nieuwe Testament ende in d'Artijckelen des Christelicken gheloofs begrepen is, niet bekendt de waerachtige ende volkomene leere der salichheit te wesen? ${ }^{9}$

7) R.B. Evenhuis, Ook dat was Amsterdam I. De kerk der hervorming in de gouden eeuw (Amsterdam: W. ten Have, 1965), 234-37. Hij meent, ten onrechte zoals nog zal blijken, dat in beide diensten dezelfde formulering voor de tweede doopvraag is gebruikt (235v). Daarvan afgeleid is de beschrijving door T. Brienen, "Doopleer en dooppraktijk in de 17e en 18e eeuw bij de gereformeerden in de Nederlanden," in Rondom de doopvont: Leer en gebruik van de heilige doop in het Nieuwe Testament en in de geschiedenis van de westerse kerk, eds. W. van 't Spijker, W. Balke, K. Exalto en L. van Driel (Kampen: De Groot Goudriaan, 1983), 373-74.

8) De remonstrantse bezwaren tegen de eerste doopvraag hadden betrekking op de daar ontwikkelde gedachte van de erfzonde. In de derde vraag werden ouders bevraagd op hun bereidheid hun kinderen 'daerin' (nl. in die 'leere') te onderwijzen. Zie voor de teksten de volgende paragraaf.

9) Dathenus 1566d (voor zover daarin vermeld hanteren we in dit artikel de afkortingen in J. van der Knijff, Heilige gezangen. Herkomst, ontwikkeling en receptie van de lofzangen in het psalmboek van Dathenus en de 'Eenige Gezangen' in de Staatsberijming van 1773 (Apeldoorn: Labarum Academic 2018), 513-62. 
Dathenus' vragen en in het bijzonder de tweede heeft in de praktijk verzet opgeroepen. Niet iedereen kon en wilde hierop antwoorden, ook omdat ouders zich nog niet met volle overtuiging tot de gereformeerde kerk gevoegd hadden. Sommige predikanten kozen er daarom voor de vragen achterwege te laten of ze als vermaning aan de ouders voor te houden. Het formulier zelf geeft daar ook wel aanleiding toe, omdat de titel boven het gedeelte met de vragen in de regel "Vermaeninge aen die Ouders, ende die mede ten doop komen" luidt. ${ }^{10}$ Niettemin schreef de provinciale synode van Zuid-Holland in 1574 kernachtig voor "dat de kerckendienaers de ouders verbinden en de de bijstaende ghetuighen vermanen sullen".11

In 1580 gaf Gaspar van der Heyden (1530-86) een herziene tekst van de catechismus en de liturgische gebeden en formulieren uit. ${ }^{12}$ De eerste en de derde doopvraag zijn praktisch ongewijzigd. De derde vraag blijft gekoppeld aan de tweede vraag: 'met name' de ouders en getuigen worden gevraagd om de kinderen 'daerin' naar vermogen te onderwijzen. De tweede doopvraag verandert wel. Hoewel deze formulering van de tweede doopvraag slechts in 1580 gedrukt is, zou deze versie een grote invloed hebben op de verdere ontwikkeling van de tweede doopvraag. De vraag in kwestie luidt:

Ten anderen, of ghy de leere, die int oude ende nieuwe Testament, ende in d'articulen onses Christelijcken gheloofs begrepen is, ende hier gheleert wort, niet bekendt de warachtighe ende volcomen leere der salicheyt te wesen. ${ }^{13}$

In deze uitgave trekt Van der Heyden ten opzichte van Dathenus 1566d "dese leere, die hier gheleert wert" uit elkaar en sneuvelt het 'voorder'. Bij Van der Heyden verandert daarnaast 'dese leer' in 'de leer' en 'wert' in 'wort'. Met deze wijzigingen verandert ook de interpretatie van het object waarnaar verwezen wordt. Waar bij Dathenus 1566d “dese leere, die hier gheleert wert”, net als het voorbeeld van Joh. à Lasco in de Londense vluchtelingengemeente, terugsloeg op de inhoud van het formulier,

10) Dathenus 1566d. Volgens het WNT (evenals ook VNMW en MNW) kan 'vermanen' de connotatie van verzoeken, vragen en smeken hebben. Instituut voor de Nederlandse Taal. "Historische woordenboeken." Geraadpleegd 12 maart 2020. http://wnt.inl.nl/.

11) J. Reitsma en S.D. van Veen, eds., Acta der Provinciale en Particuliere Synoden [... ] II (Groningen: J.B. Wolters, 1893), 136 (Dordrecht 1574). Even later echter op dezelfde dag besloot de synode: "De Vaders sijn ghehouden ende behooren vermaent te worden bij den Doop harer kinderen te sijn, opdat sij met den ghevaderen de voorghestelde vraghen beantwoorden," Reitsma en Van Veen, Acta II, 137 (curs. KWdJ). Zie ook De Jong en De Jong, “Van forme naar formulier," 23.

12) Gaspar van der Heyden, ed., Catechismus ofte onderwysinghe inde Christelijcke Religie [...] Mitsgaders de Christelijcke Ceremonien ende Ghebeden. Met neersticheyt ouersien ende ghecorrigeert [...] (Antwerpen: Nicolaes Soolmans, 1580). De gelijkluidende uitgave (Antwerpen: Gielis van den Rade) is een herdruk, zie W. Heijting, De Catechismi en Confessies in de Nederlandse Reformatie tot 1585 I (Nieuwkoop: De Graaf, 1989), 26669. Voor Van der Heyden, zie BLGNP II, 243-246. Voor de kerkelijke status van de teksten, zie De Jong en De Jong, "Van forme naar formulier," 24-27.

13) Van der Heyden, Catechismus, 52. 
heeft 'de leere' in de uitgave van Van der Heyden betrekking op hetgeen in de Bijbel en de christelijke belijdenis te vinden is en 'hier geleerd wordt'. ${ }^{14}$ Het 'hier gheleert' verandert van plaats en in de gewijzigde context mogelijk ook van betekenis. Bij ‘hier' kan namelijk ook gedacht worden aan de (gereformeerde) kerk ter plaatse. Ook eerdere Dathenus-uitgaven zijn overigens zo wel geïnterpreteerd. In verschillende Dathenus-uitgaven is namelijk de doopvraag geformuleerd als "dese leere die hier gheleert wort". ${ }^{15}$ Ook is het werkwoord in verscheidene uitgaven al dan niet bewust weggelaten. ${ }^{16}$ Waar echter de versie van Van der Heyden's doopvragen slechts tweemaal gedrukt is in 1580, blijft de versie van Dathenus $1566 \mathrm{~d}$ in ieder geval tot en met 1585 nagenoeg ongewijzigd gedrukt worden. ${ }^{17}$

Het zal duidelijk zijn dat Van der Heyden geen oplossing bood voor degenen die moeite hadden met het beperkende karakter van de tweede doopvraag. Toch heeft zijn tekst aan de basis gestaan van de formulering die de synode van 's-Gravenhage (1586) vaststelde. ${ }^{18}$ De set formulieren waar ze deel van uitmaakte is vooral in Zuid-Holland expliciet aanvaard. ${ }^{19}$ In de, voor zover bekend, eerste publicatie van deze aanpassing, in 1589, is dit de tweede doopvraag:

Ten anderen, Oft ghy de leere die int oude ende nieuwe Testament, ende in den Artijckelen des Christelicken gheloofs begrepen is, ende dien volghende in de Christelicke kercke gheleert wert, niet bekent de warachtighe ende volcomene leere der salicheyt te wesen? ${ }^{20}$

Als antwoord op de eerste en tweede vraag tezamen is 'Ja wy' is opgenomen. ${ }^{21}$ Deze tekst - hierna aangeduid als de formulering van 1586 - van de tweede doopvraag wordt ook in verreweg de meeste latere edities tot aan de Dordtse synode van $1618-19$ gevonden. ${ }^{22}$ Ten opzichte van de editie van Van

14) De Jong en De Jong, "Van forme naar formulier," 36-39.

15) Zo bijvoorbeeld (NB: curs. auteurs): Dathenus 1579g, Dathenus 1581d.

16) Zo bijvoorbeeld: Dathenus 1579h, 1582a en 1584b.

17) Zo blijkt uit het nalopen van de tot nu toe 48 bekende edities na de verschijning van Dathenus $1566 \mathrm{~d}$ (Van der Knijff, Heilige gezangen, 514, 517-23).

18) Zie voor het karakter van dit vaststellen De Jong en De Jong, "Van forme naar formulier," 27.

19) Expliciet: Reitsma en Van Veen, Acta II, 299 (Delft 1587). Zie verder een nog te publiceren artikel van E.A. de Boer over onder meer de acceptatie van de Haagse formulieren.

20) Dathenus 1589a. Het handschrift uit 1586 kent een licht afwijkende tekst: "Ten anderen oft ghij de leere des Ouden ende des Nieuwen Testaments die inde articulen des Christens gheloofs begrepen is, en dien volgende in de christelijcke kercke geleert wordt". Het manuscript ligt in het Nationaal Archief 's-Gravenhage, “Archief classis Dordrecht 1573-1959," inv. nr. 77. Voor dit artikel is na vergelijking met het handschrift de tekst van de doopvragen in L.A. van Langeraad, "De Kerkorde, gearresteerd in de Nationale Synode [... ] 1586, benevens de toen vastgestelde formulieren," Navorscher 51 (1901): 347-83, 432-60, 437.

21) Op de derde vraag wordt een apart antwoord verlangd. Daar is een simpel 'Ja' vermeld.

22) De Jong en De Jong, "Van forme naar formulier," 52. Vgl. ook H.H. Kuyper, De Post-Acta of Nahandelingen van de Nationale Synode van Dordrecht in 1618 en 1619 gehouden (Amsterdam-Pretoria: Höveker \& Wormser, 1899), 158 die dit gegeven bijna terloops vermeldt, hoewel het zijn betoog dat het nog maar de vraag is of deze variant wel in 1586 is vastgesteld bepaald niet ondersteunt. 
der Heyden is "ende hier gheleert wort" gewijzigd in "ende dien volghende in de Christelicke kercke geleert wert". Net als bij de verschillende Dathenus-uitgaven geldt ook voor de formulering van 1586 dat de 'wert' ook wel gedrukt is als 'wor(d)t'. ${ }^{23}$ De formulering van 1586 trekt hetgeen geleerd werd breder dan Dathenus en Van der Heyden: het gaat om de leer zoals die uit de Bijbel en de christelijke belijdenis opkomt en omdat zij op deze wijze gefundeerd is in de christelijke kerk geleerd wordt. Ook wie tot een ander kerkgenootschap behoorde, kon daarop met een goed geweten antwoorden, ${ }^{24}$ al moet niet worden uitgesloten dat de vragensteller bij christelijk exclusief aan gereformeerd dacht. Deze verruiming is ook terug te zien in de derde vraag. Het 'daerin' van Dathenus dat verwees naar 'de leere' uit de tweede doopvraag waarin het kind dient te worden opgevoed, is vervangen door een veel algemenere formulering, namelijk “inde voorseyde leere".

Er waren echter predikanten die ook met een variant van de vraag als deze niet uit de voeten konden. Een voorbeeld daarvan is de Goudse predikant Herman Herberts (1540/44-1607). Deze verzette zich tegen een exclusief gereformeerde aanpak en door de 17e-eeuwse remonstranten tot hun voorlopers is gerekend. ${ }^{25}$ De Zuid-Hollandse provinciale synode te Schoonhoven beschuldigde hem nog in 1597 onder meer van "in de plaetse van affvraginghen voor den doop simpele vermaninghen ghebruyckt" te hebben. ${ }^{26}$ Het probleem over het al dan niet stellen bleef ook elders actueel. In Friesland bijvoorbeeld komt het op voorslag van de classis Bolsward in 1609 aan de orde en wordt toegestaan de vragen zo nodig ook 'leerenswijze' te hanteren. ${ }^{27}$ Wijzigt de motivatie ten aanzien van het weglaten van de doopvragen, waarbij het niet meer alleen gaat om de doopouders die niet op de vragen kúnnen antwoorden, maar ook om de predikant die ze op grond van hun inhoud niet meer wílde stellen? Dat is net als bij Herberts waarschijnlijk het geval in de vraag die de classis Kampen in 1612 op tafel legde bij de provinciale synode van Overijssel:

off die 3 vragestucken voor middelmatige offte wesentlicke deelen des doopes tho achten zijn, maer off sie daran well doen, dat sie dieselvigen vragen achterwegen laten tegen die resolutie synodi generalis, so binnen Dordrecht anno 74 als binnen Middelborch anno 81 geholden. ${ }^{28}$

23) Handschrift: zie noot 20; verder Catechismus, oft Onderwijsinge inde Christelijcke Religie [... ]

(Middelburg: Richard Schilders, 1591), Catechismus ofte Onderwijsinge inde Christelicke Leere [... ] (Middelburg: Richard Schilders, 1611).

24) De remonstranten lijkt het zo ook te hebben opgevat (vgl. Brandt, Historie der Reformatie II, 222).

25) BLGNP III, 178-81, 178.

26) J. Reitsma en S.D. van Veen, eds., Acta der Provinciale en Particuliere Synoden [... ] III (Groningen: J.B. Wolters, 1894), 85 (Schoonhoven 1597); vgl. 106 (Dordrecht 1598).

27) J. Reitsma en S.D. van Veen, eds., Acta der Provinciale en Particuliere Synoden [... ] VI (Groningen: J.B. Wolters, 1897), 183v. In J.J. Kalma, ed., Een kerk in opbouw. Classisboek Bolsward-Workum, 1600-1633 (Leeuwarden: Fryske Akademy, 1981), is het punt niet terug te vinden (met dank aan J.D.Th. Wassenaar die dit voor mij nazocht).

28) J. Reitsma en S.D. van Veen, eds., Acta der Provinciale en Particuliere Synoden [... ] V (Groningen: J.B. Wolters, 1898), V, 290 (Kampen 1612); vgl. 294 (Zwolle 1615) en 307 (Vollenhove 1618). 
Deze door het in Kampen achterwege laten van de doopvragen aangezwengelde kwestie zou uiteindelijk tot een gravamen leiden van Overijssel voor de synode van Dordrecht 1618-19, maar dit zal die synode om onduidelijke redenen niet bereiken. ${ }^{29} \mathrm{E}$.A. de Boer vermoedt in zijn monografie over het remonstrantisme in Kampen dat met name de erfzonde in de eerste vraag op bezwaren zal zijn gestuit. ${ }^{30}$ De 'leere' uit de tweede vraag lijkt in Kampen niet direct verzet op te roepen. Nadrukkelijk wordt in 1612 in het aangebrachte agendapunt ook de synode van Middelburg 1581 genoemd. Die liet nu juist ruimte om "dese maniere van spreecken (de leere die hier gheleert wordt)" - in feite alleen: "die hier gheleert wordt" - in de tweede doopvraag van Dathenus achterwege te laten. ${ }^{31}$ Maar ook zo konden de Kamper predikanten kennelijk nog onvoldoende uit de voeten.

\section{De beschikbare bronnen}

Naast de aantekeningen in de doopboeken is allereerst een drietal brieven beschikbaar, alle uit 1613. De eerste brief is afkomstig van Hugo de Groot, gesteld in het Latijn, gedateerd 22 juni 1613, en gericht aan Isaac Casaubon (1559-1614). ${ }^{32}$ De Groot had deze naar Engeland gevluchte geleerde daar in 1613 ontmoet, nadat hij al eerder met hem had gecorrespondeerd. ${ }^{33}$ Deze brief is bij mijn weten in de beschrijvingen tot op heden niet gebruikt en handelt over beide doopdiensten. De tweede brief is van van Wtenbogaert aan de predikant die de vragen stelde, Petrus Plancius (1552-1622). De brief is integraal opgenomen in Wtenbogaerts De kerckelicke historie (1646). ${ }^{34} \mathrm{Hij}$ wordt ook terloops genoemd in zijn autobiografie. ${ }^{35}$ De derde brief is door Episcopius geschreven aan Wtenbogaert en afgedrukt in G.

29) Kuyper, De Post-Acta, 444n3.

30) E.A. de Boer, De macht van de minderheid. Het remonstrantisme in Kampen in de spiegel van de nationale synode te Dordrecht (1618-1619) (Kampen: Summum, 2019), 28.

31) F.L. Rutgers, ed., Acta van de Nederlandsche Synoden der zestiende eeuw ('s-Gravenhage: Martinus Nijhoff, 1899), 407. Bij dit besluit rijzen twee samenhangende vragen. Wat was de redactie van de vraag en wat betekende het besluit voor die redactie. In Datheens eerste uitgave luidde de tweede vraag immers: "Ten anderen, of ghy dese leere, die hier gheleert vvert, ende voorder, ... niet bekendt de vvaerachtige ende vokomene leer der salicheit te vvesen" (Dathenus 1566d). Vermoedelijk zal bedoeld zijn de woorden "hier gheleert vvert, ende voorder," te laten vervallen.

32) Molhuysen, Briefwisseling I, 248-51 (briefnr. 272: H. de Groot aan I. Casaubon d.d. 22 juni 1613).

33) H.J.M. Nellen, Hugo Grotius. A Lifelong Struggle for Peace in Church and State, 1583-1645 (Leiden-Boston: Brill, 2015) 152 (eerste ontmoeting; brieven: passim).

34) Wtenbogaert, De Kerckelicke Historie, 609-11 (J. Wtenbogaert aan P. Plancius d.d. [17-21?] februari 1613). Een afschrift zou gezonden zijn aan kerkenraad en burgemeesters. In de desbetreffende archieven is een dergelijk stuk echter niet terug te vinden (GAA, Inventaris van het Archief van de Burgemeesters, missiven aan burgemeesters; Inventaris van het Archief van de Hervormde Gemeente, kerkenraad). Wtenbogaert en Plancius kenden elkaar uit eerdere confrontaties. Zie voor Plancius verder BLGNP III, 291-95.

35) J. Wtenbogaert, Johannis Wtenbogaerts Leven, Kerckelijcke Bedieninghe ende zedighe Verantwoordingh [...] (['s-Gravenhage: Anthony Jansz,] 1645), $198 \mathrm{v}$. 
Brandts Historie der Reformatie (1674)..$^{36}$

De remonstrant Brandt heeft voor zijn geschiedschrijving de beschikking gehad over een schat aan archivalia. De originelen van de tweede en de derde brief lijken echter op enig moment verloren te zijn gegaan. Het is onduidelijk in hoeverre ze getrouw zijn weergegeven en een getrouwe weergave bevatten. Het gaat bij de auteurs van de drie brieven om remonstranten die elkaar goed gekend hebben en voor de remonstrantse zaak gestaan zullen hebben. Zo woonde De Groot rond de eeuwwisseling enige tijd bij Wtenbogaert in en had hij met beiden intensief contact. ${ }^{37}$ Van gereformeerde zijde zijn er na het tweede incident de kerkenraadsnotulen. Onder druk van de Amsterdamse burgemeesters moest de kerkenraad een standpunt innemen ten aanzien van de te bezigen tweede doopvraag. Aan beide zijden ontbreekt het in deze periode aan publicaties waarin de feiten nauwkeurig op een rijtje worden gezet. Die deden de ronde en werden kennelijk bekend geacht. Toen Wtenbogaert in 1617 in het geschrift dat bekend is geworden als tweede remonstrantie, aan de Amsterdamse situatie refereerde, deed hij dat in vrij algemene termen. ${ }^{38}$ Trigland reageerde specifieker, maar was weinig trefzeker in zijn citaten van de in zijn optiek oude en nieuwe formuleringen en hield zich over de precieze gang van zaken in Amsterdam op de vlakte. ${ }^{39}$

Een tweede belangrijke categorie bronnen is een reeks publicaties van ongeveer dertig jaar later. De feiten waren toen al lang niet meer bekend onder een breed publiek. Ze moesten opnieuw onder de aandacht worden gebracht en van een duiding worden voorzien. Een aantal ooggetuigen was toen nog steeds in leven. Het begon met een remonstrantse uitgave over leer en liturgie, Onderwysinge in de Christelijcke Religie [... ] (1640), een anoniem gepubliceerd geschrift van Episcopius en Wtenbogaert dat als zodanig overigens in een langere reeks van publicaties stond waarin gereformeerden en remonstranten de degens kruisten. ${ }^{40}$ Op deze Onderwysinge reageerden diverse gereformeerde theologen. We noemen er drie. De eerste was Trigland met de bijdrage "Voor-reden Gestelt teghen

36) Brandt, Historie der Reformatie II, 217-220 (S. Episcopius aan J. Wtenbogaert d.d. 3 april 1613). Vgl. ook S. Episcopius aan A. van den Borre d.d. 6 april 1613 (in Praestantium ac eruditorum virorum epistolae ecclesiasticae et theologicae [... ] (Amsterdam: Henricus Dendrinus, 1660), 393v (brief nr. 208): alle Amsterdamse predikanten zouden gewoonlijk gebruik hebben gemaakt van het formulier dat in 1586 zou zijn vastgesteld, behalve Plancius, maar ook die slechts van tijd tot tijd.

37) Inwonen: Nellen, Hugo Grotius, 76-78; intensieve contacten: passim.

38) [J. Wtenbogaert,] Copye van seker Vertooch. Onlangs by eenighe Predicanten der Ghereformeerde kercke ghedaen anede Ho. Ed. Heeren Staten van Hollandt ende West-Vrieslandt [... ] (Delft: Bury H. Schinckel, 1617).

39) J. Trigland, Klaer ende grondich Tegen-vertoogh, van eenighe Kercken-Dienaren van Hollant ende WestVrieslandt [... ] (Amsterdam: Marten Jansz. Brandt, 1617), 83vv. Vgl. ook J. Trigland, Ontmoeter bejeghenende den Voor-bode vande Antwoordt [... ] (Amsterdam: Marten Jansz. Brandt, 1617), 15-18.

40) Onderwysinge in de Christelijcke Religie, Ghestelt Bij Vragen ende Antwoorden na de Belijdenisse der Remonstrants-Ghereformeerde Christenen. Midtsgaders der selfder formulieren ende Ghebeden, des H. Doops ende des H. Avondtmaels. [Ioannes Naeranus, Rotterdam 1640]. Over dit geschrift hoopt Klaas-Willem de Jong later uitgebreider te publiceren. Over het auteurschap: H.C. Rogge, Johannes Wtenbogaert en zijn tijd III (Amsterdam: Y Rogge, 1876), 292, 326. 
de Voor-reden Van den Remonstrantschen Catechismus" in zijn verzameld werk Opuscula (1640). ${ }^{41}$ Trigland was aanwezig bij de doopdienst op 2 april 1613 en geeft voor het eerst een wat uitvoeriger verslag van de wederwaardigheden, vermoedelijk op basis van eigen waarneming en herinnering. Daarop volgde Gisbertus Voetius met Catechisatie Over den Catechismus der Remonstranten (1641), in 1613 predikant in Vlijmen en Engelen, toen dus op afstand..$^{42}$ In 1640 was tevens een vergelijkbare reactie verschenen van Abraham Heydanus (1597-1678), zoon van de Gaspar van der Heyden jr. die op 2 april 1613 de vragen had gesteld, overigens zonder dat Abraham expliciet verwees naar de gebeurtenissen van $1613 .{ }^{43}$ Simon Episcopius ging hier vervolgens op in met zijn Antwoort op de Proeve van Abrahamus Heydanus $[\ldots](1643) \cdot{ }^{44}$

In een soort van proloog in Episcopius' Antwoort kiest Wtenbogaert, van wie uit andere bron bekend is dat hij de auteur was, voor een uitvoerige bespreking van hetgeen in april 1613 is voorgevallen. ${ }^{45}$ Waren in de hiervoor gegeven publicaties de gestelde vragen wel gedeeltelijk of vrijwel geheel geciteerd, in Wtenbogaerts "Vrymoedige Weder-spraeck" worden ze nu ook aan remonstrantse zijde ingebed in een uitvoerig, apologetisch getoonzet relaas van de gebeurtenissen van de ze april. Het zou voor de hand hebben gelegen als Wtenbogaert hiervoor de brief die Episcopius aan hem zond zie boven - direct zou hebben gebruikt, maar dat is onwaarschijnlijk. Wtenbogaert noemt de brief in 1643 niet. Hoewel hier en daar frases en zinswendingen bekend voorkomen, verschillen volgorde der gebeurtenissen en citaten in de autobiografie op onderdelen wezenlijk van de aan hem gericht brief. Naar verluidt heeft Wtenbogaert veel gebruik gemaakt van eigen aantekeningen en andere documentatie voor zijn autobiografie, al laat dat voor de betrouwbaarheid vragen open, zoals ook uit de beschrijving van deze gebeurtenis blijkt. ${ }^{46}$ In de autobiografie verhaalt hij alleen van de doopdienst waar hijzelf direct bij betrokken was, die van 14 februari. ${ }^{47}$ De beschrijvingen van 14 februari en 2 april komen samen in de postuum uitgegeven Kerkelycke Historie [... ] (1645). Triglands Kerckelycke geschiedenissen [... ] (1650) biedt vervolgens een uitvoerige, kritische bespreking in contraremonstrants perspectief van deze beschrijvingen.

41) J. Trigland, Opuscula Jacob Triglandii. Dat Is, Verscheyden Boecken en Tractaten I [... ] (Amsterdam: Marten Jansz Brandt, 1640), “Voor-reden” (voor dit artikel van belang m.n. 26-31).

42) G. Voetius, Catechisatie Over den Catechismus der Remonstranten [... ] (Utrecht: Esdras Willemsz Snellaert, 1641), “Aen-merckingen. Over den Tijtel des Boecks ende de Voor-reden," sub II.

43) Abrahamus Heydanus, Proeve Ende Wederlegginghe des Remonstrantschen Catechismi (Leiden: Paulus Aertsz van Ravesteyn en David lansz, 1641). Zie voor de achtergrond van Heydanus ook: BLGNP II, 240-243 (m.n. 241).

44) S. Episcopius, Antwoort Op de Proeve van Abrahamus Heydanus, Tegen de Onderwysinge [...]

(Rotterdam: Joannes Naeranus, 1643), “Vrymoedige Weder-spraeck op de harde Aen-spraeck” (NB: zonder paginering).

45) Ph. Van Limborch, Leven van Simon Episcopius. Eertijdts Professor der H. Theologie tot Leyden (Amsterdam: Izaak Pietersz., 1693), 316.

46) H.C. Rogge, Johannes Wtenbogaert en zijn tijd III (Amsterdam: Y Rogge, 1876) 327v.

47) Wtgenbogaert, Leven, $198 \mathrm{v}$. 


\section{De gestelde vragen}

Volgens Hugo de Groot heeft in beide diensten de vraag geklonken:

of gij niet bekent deze leer die hier geleerd wordt, en voorts in het Oude en Nieuwe Testament en in de artikelen van het christelijke (geloof) is vervat, de waarachtige en volkomen leer der zaligheid te wezen? ${ }^{48}$

Voor de tekst die het in zijn ogen had moeten zijn, wijst hij op de synode van 's-Gravenhage (1586) en geeft in het Latijn de tekst die hierboven ook geciteerd is uit de Biblia van Jan Paedts (1589), zij het dat hij expliciet gewaagt van een besluit: de synode "inter cuius Canones unus est ut ...". ${ }^{49}$ Hij legt uit dat de wijziging op zijn plaats is: eerst de Schrift, op de tweede plaats het gezag van de Kerk. ${ }^{50}$ Nadere beschouwing leert dat de tekst die De Groot typeert als de 'oude formule' de doopvraag is van Dathenus zoals die in diens eerste editie van 1566 en in vele uitgaven daarna te vinden is. ${ }^{51}$ Als Wtenbogaert in zijn Kerkelijcke Historie van de gebeurtenis verhaalt, dan gebruikt hij in eerste instantie ook precies deze formule..$^{52}$ De brief die hij vervolgens aan de steller van de doopvragen, Petrus Plancius, geschreven zou hebben en in extenso opneemt in zijn historisch relaas, suggereert iets anders. Suggereert: Wtenbogaert citeert namelijk slechts een deel, dat overigens sterk lijkt op de tekst die hij in zijn autobiografie gebruikt:

[of gij niet bekent] De Leere in't Oude ende Nieuwe Testament, en in de Articulen des Christelijcken Geloofs begrepen ... ende alhier, of in dese kercke, of, in dese Christelijcke kercke [geleerd wordt, de waarachtige en volkomen leer der zaligheid te zijn.$^{53}$

48) "Nonne fateris eam doctrinam quae hic docetur, et praeterea in Veteri ac Novo Testamento et articulus (Fidei) Christianae continetur, esse veram et perfectam ad salutem doctrinam?” Molhuysen, Briefwisseling I, 248, 250; briefnr. 272, H. de Groot aan I. Casaubon d.d. 22 juni 1613 (curs. De Groot)). NB: De Groot kiest met 'docetur' voor een praesens passief, 'geleerd wordt'.

49) Molhuysen, Briefwisseling I, 248 (briefnr. 272: H. de Groot aan I. Casaubon d.d. 22 juni 1613). De vraag is hoe De Groot dit weet. De acta waren namelijk verdwenen. Vgl. ook De Jong en De Jong, "Van forme naar formulier," 27-29, 38-40: vermoedelijk is sprake van een misverstand; waarschijnlijk gaat het om een bepaling in de door de Staten van Holland opgestelde kerkorde van 1583.

50) Molhuysen, Briefwisseling I, 248v.

51) Dathenus 1566d. Vgl. Molhuysen, Briefwisseling I, 250.

52) Wtenbogaert, Kerckelijcke Historie, 609. Vgl. ook de qua woordvolgorde iets afwijkende variant in Brandt, Historie der Reformatie II, 216.

53) Wtenbogaert, Kerckelijcke Historie, 610 (curs. Wtenbogaert). Vgl. Wtenbogaert, Leven, 70: “Of wy niet en gheloofden, dat de leere, begrepen in 't Oude ende Nieuwe Testament, ende de Articulen des Christelijcken Geloofs, ende die ... alhier in deze Kercke ... geleert wierdt, de volcomen leere der saligheydt" te zijn. 
Trigland houdt het in zijn verschillende geschriften op de formulering van Dathenus. ${ }^{54}$ Brandt zal dat later ook doen. ${ }^{55}$ Dat gevoegd bij het relaas van De Groot menen wij dat dit citaat van Wtenbogaert geëlimineerd kan worden. Plancius hanteerde de Dathenus-versie van 1566, of althans een variant die daar sterk op lijkt. Het jawoord van Wtenbogaert op de gestelde doopvraag leidde ertoe dat hij daags daarna op straat nageroepen werd: hij zou middels instemming met de gereformeerde leer zijn eigen remonstrantse overtuiging verloochend hebben.

Dan komen we nu toe aan de tweede doopdienst. De Groot maakt in het gebruik van de formule geen onderscheid tussen beide diensten. Ten onrechte, zo blijkt. Wat zeggen namelijk de andere bronnen over de ze april en de vragen die Gaspar van der Heyden jr. (1566-1626) toen stelde?56 Wtenbogaert houdt het in zijn verslag uit 1643 op:

[of gij niet bekent] die Leere, die in 't Oude ende Nieuwe Testament, ende in de Artijckelen des Christelijcken Geloofs begrepen is, ende in dese Kercke als nu geleert wort [de waarachtige en volkomen leer der zaligheid te zijn]. ${ }^{57}$

De brief van Episcopius die Brandt in zijn kerkgeschiedenis heeft opgenomen, ligt dicht aan tegen hetgeen Wtenbogaert in zijn De Kerkelicke Historie heeft vermeld. Episcopius schrijft:

[of gij niet bekent] 't geene in het Oude en Nieuwe Testament en in de artijkelen des Christelijken geloofs begrepen is, en 't geen alhier geleert wordt, de waerachtige en volkomene leere der saeligheit te wesen $?^{58}$

De weergave van Trigland in de "Voor-Reden" van zijn Opuscula bevat een gegeven dat helderheid biedt over de redactie van deze vragen. Van der Heyden jr. had in de confrontatie na de dienst, in het bijzijn van de andere aanwezige predikanten gemeld gebruik gemaakt te hebben van "sijn Boecxken dat hy ordinaerlijck ghebruyckte om daer uyt het Formulier vanden Doop voor te lesen, waer uyt hy oock te dier tijdt het selve voorgelesen hadde, ... van sijn vader ... uyt-ghegeven”. ${ }^{9}$ Dit moet de uit 1580 daterende uitgave Catechismus ofte onderwysinghe van Gaspar van der Heyden zijn. De tweede

54) Trigland, Opuscula, “Voor-Reden," 26, 28, 30 (vgl. Triglands Tegen-Vertoogh, 83vv); Kerkelycke geschiedenissen, 658 .

55) Brandt, Historie der Reformatie II, 216. Vgl. H.C. Rogge, Johannes Wtenbogaert en zijn tijd II (Amsterdam: Y. Rogge, 1875), 230, die net als Triglands Klaer ende grondich Tegen-vertoogh zo weergeeft dat de oorsprong van de vraag niet zonder meer te herleiden valt.

56) Hij is de zoon van de gelijknamige uitgever van de liturgische formulieren in 1580. Zie verder voor hem: NNBW III, K. 583.

57) Episcopius, Antwoort op de Proeve, "Vry-moedig weder-spraeck".

58) Brandt, Historie der Reformatie IV, 217. Vgl. Wtenbogaert, De Kerckelicke Historie, 611. Deze weergave is niet bestreden door Trigland (Kerckelycke Geschiedenissen, 661-664).

59) Trigland, Opuscula, "Voor-Reden", 29. 
doopvraag in deze uitgave sluit namelijk aan bij de hierboven geciteerde.

Episcopius reageerde naar eigen zeggen op de vraag met:

dat ik mijnenthalven, hielde waerachtig te wesen 't geene volgens Godes woordt en d'artijkelen des Christelijken geloofs geleerdt wierde, nae den inhoudt van het formulier, DIENVOLGENDE. ${ }^{60}$

Hierop volgde in de dienst een scherpe uiteenzetting tussen Van der Heyden jr. en Episcopius, na de dienst door enkele Amsterdamse collega-predikanten voortgezet. ${ }^{61}$ Op straat werd hij onheus bejegend. Episcopius benadrukt in de geciteerde zin het belangrijkste onderscheid tussen de varianten van 1580 en 1586: voor het 'hier' komt het “dienvolgende inde Christelijcke kercke” in de plaats. Voor zover hij van een 'hier' wil weten, interpreteert hij dat als verwijzend "nae den inhoudt van het formulier".

Trigland lijkt in zijn Opuscula (1640) nog niet te beseffen dat het in de tweede dienst niet om Dathenus' vraag ging maar om die van Van der Heyden sr. uit 1580. Hij meent dan ook te kunnen bewijzen dat de vraag van Van der Heyden "niet nieuw, maer geheel out is". ${ }^{62}$ Trigland citeert dan ook rijkelijk uit zijn oude Tegen-Vertoogh (1617), waarin hij reageerde op een eerdere beschuldiging van Wtenbogaert dat niet de remonstranten maar de contraremonstranten nieuwigheden invoerden. Wtenbogaert stelde indertijd dat "in de ghemeyne formulieren doorgaens in alle kercken gebruyckelick" gevraagd werd naar de leer "sonder daer by te doen van dese leere die hier of daer gheleert wort". Hij specificeerde dat niet nader. In zijn Kerckelycke Geschiedenissen (1650) bestrijdt Trigland Wtenbogaert op alle mogelijke punten, maar niet wat betreft de tekst van de gestelde doopvraag zoals Wtenbogaert die in De Kerkelicke Historie weergeeft. ${ }^{63}$ Inmiddels heeft Voetius dan ook aangetoond dat over een lange periode, tot ver na de synode van Dordrecht 1618-19, de vraag van Dathenus in gedrukte edities van het doopformulier voorkomt. Maar ook dat er "een weynich verschillende" variant is in de uitgave van Van der Heyden. ${ }^{64}$

60) Brandt, Historie der Reformatie II, 217. Vgl. Episcopius, Antwoort, "Vrymoedige Weder-spraeck," waarin het antwoord luidt: "Al wat, volgende Gods woort, ende de Artijckelen des Christelijcken Geloofs hier geleert wort, la". Vgl. ook Trigland, Opuscula, "Voor-Reden," 29, die stelt dat Episcopius wat mompelde.

61) Volgens Episcopius waren “veel meer Predikanten ... dan na gewoonte” (Brandt, Historie der Reformatie II, 223) aanwezig: in ieder geval Van der Heyden jr. (1566-1626), Trigland, Hallius, Le Maire, Ursinus en Geldorpius (Episcopius, Antwoort, "Vrymoedige Weder-spraeck" (volledige titel, zie hierna noot 50).

Trigland vermeldt naast Van der Heyden jr. met name Hallius en Ursinus (Trigland, Kerckelycke Geschiedenissen, 663; idem Brandt, Historie der Reformatie II, 219), hetgeen overigens een groter aantal niet uitsluit. Vreemd is dat de predikant die volgens het doopboek gedoopt zou hebben, Petri van Niedek, niet genoemd wordt.

62) Trigland, Opuscula, "Voor-Reden." Hij verwijst slechts naar de ambigue tekst van Tegen-Vertoogh. Daar (83v) geeft hij een verbasterde vorm van Datheens vraag.

63) Vgl. Trigland, Kerckelycke Geschiedenissen, 662.

64) Voetius, Catechisatie, “Aen-merckingen,” sub II. 
Trigland laat in zijn Tegen-Vertoogh (1617) en ook opnieuw in zijn Opuscula (1640) nog in het midden welke vragen gebruikelijk waren in Amsterdam. In de Kerkelycke geschiedenissen (1650) erkent hij echter impliciet dat op de kansel van de Amsterdamse kerken de formulieren in de formulering van 's-Gravenhage 1586 te vinden waren. ${ }^{65}$ Daarin stemt hij overeen met remonstrantse bronnen. ${ }^{66}$ Volgens Trigland namen de oudste predikanten een eigen exemplaar mee en gebruikten de jongere het kanselboek. Hoewel beseft moet worden dat dit Trigland goed past in zijn gereformeerde apologie, achten we het een waarschijnlijke verklaring, ook omdat de kerkenraadsnotulen van 11 april 1613 melding maken van de wens van de burgemeesters de doop te bedienen volgens het formulier "nu byde meeste der Predicanten gebruyct". ${ }^{67}$ Niettemin verschuift bij Trigland de argumentatie. Waar hij eerst benadrukt dat de tekst van Van der Heyden 1580 oud was en de formulering van 1586 geen kerkelijke goedkeuring gekregen zou hebben, ${ }^{68}$ ligt het accent er nu op bij gebruik van zowel de oude (Dathenus 1566 én Van der Heyden 1580) als de nieuwe tekst, “dat het alle beyde op een uyt quam”. ${ }^{69}$ Een kerk waar deze leer niet geleerd wordt, kan geen christelijke kerk genoemd worden.

Op het genoemde verzoek van de burgemeesters reageert de kerkenraad even vriendelijk als dringend "de kercke haer vryheyt te laten". ${ }^{70}$ Toen de burgemeesters aanhielden, ging de kerkenraad in een extra vergadering op 16 april alsnog overstag..$^{71} \mathrm{Hij}$ besloot in de doopvraag van het formulier in te voegen "End volgens dien alhier in dese Christel. Kercke geleert wort". Hij merkte daarbij wel op dat het voorlopig was, totdat de gereformeerde kerken hierover nader gezamenlijk besloten zouden hebben. Het alhier heeft in deze formulering ondubbelzinnig betrekking op de christelijke kerk. Het gaat om de christelijke kerk te dezer plaatse. Het invoegen van de zinsnede is praktisch alleen denkbaar in de gegeven zinsopbouw van de formulierversies van Van der Heyden sr. en de daarop voortbouwende variant van synode van 's-Gravenhage 1586. De vrijheid die Plancius zich veroorloofde met een oude Dathenus-versie werd door dit afgedwongen kerkenraadsbesluit onmogelijk gemaakt.

De remonstranten hebben het gevoel gehad dat zij in beide doopdiensten bewust in de val zijn gelokt. De kerkenraadsnotulen maken duidelijk dat het gebruik van bepaalde vragen tweeërlei doel had: "ten eynde de goude eenuoudige Gem. ${ }^{\text {te }}$ int herte niet en werde beroert, ende oock opDat de

65) Trigland, Kerckelycke Geschiedenissen, 663.

66) Vgl. bijvoorbeeld Episcopius, Antwoort, “Vrymoedige Weder-spraeck”: “de platte Boeckjens, die op den Predick-stoel van Anno 1586. gebruyckt waren”; Wtenbogaert, De kerckelicke historie IV, 612; Brandt, Historie der Reformatie II, 222.

67) Rutgers, Het kerkverband, 103.

68) Trigland, Opuscula, "Voor-Reden."

69) Trigland, Kerkelycke geschiedenissen, 613v (citaat: 614).

70) Rutgers, Het kerkverband, 103 (11 april 1613). Vgl. 16 april 1613: “oude vryheyt". Evenhuis interpreteert het verslag als zou het gaan om de tekst die op de kansel lag, die van de synode van 's-Gravenhage 1586 (Evenhuis, Ook dat was Amsterdam I, 236). Mijns inziens valt dat niet uit de notulen op te maken.

71) Rutgers, Het kerkverband, 103 (16 april 1613). 
Huychelaers te meer geweert mogen worden." ${ }^{2}$ Het is niet vreemd dat Episcopius en Wtenbogaert het gevoel hadden op de proef te zijn gesteld. Toch kan op basis van deze passage niet worden bewezen dat dit doelbewust is gebeurd, al was het maar omdat in de overwegingen van de kerkenraad ook het voeden van het vertrouwde een rol speelde, en de predikanten in de doopdiensten ook hier bewust rekening mee hielden.

\section{De doorwerking van de incidenten}

Evenhuis meent in Ook dat was Amsterdam, dat de kerkenraad hiermee kool en geit gespaard heeft: het 'alhier' uit de oude versie, het 'volgens dien' overeenkomstig de synode van 's-Gravenhage. ${ }^{73}$ Het is dan wel opvallend dat de Noord-Hollandse afgevaardigden naar de synode van Dordrecht in 1618-19 de vraag hebben opgeworpen of in de tweede doopvraag 'End dien volgende ind' Christelyke kerke geleert wert' het woordje 'alhier' zou moeten worden ingevoegd en daarop antwoorden met 'Wy meenen Jae'. ${ }^{74}$ Het 'dien volgende' is in deze vraag op dat moment kennelijk toch een gegeven. Vier van de zes Noord-Hollandse afgevaardigden waren Amsterdammers, onder hen de predikanten Trigland en Rolandus. De laatstgenoemde was in 1613 een van de kerkenraadsleden die het gesprek met de burgemeesters hadden moeten voeren. De vraag zal hoogstwaarschijnlijk door de Amsterdamse leden zijn opgeworpen, buiten de vergaderingen van classis en particuliere synode om. Trigland meent in zijn Kerkelycke Geschiedenissen dat de Dordtse synode 1618-19 ook een eenparig besluit heeft genomen over de invoeging van het woordje "alhier ofte in dese Kercke". ${ }^{75}$ Feit is dat het na de Dordtse synode nog zeker twee decennia zou duren voor de situatie op dit punt tot rust kwam. Tot dan komen wij Dathenus 1566 tegen, maar ook de formulering 's-Gravenhage 1586 en de 'Amsterdamse' variant. ${ }^{76}$ Pas toen de standaard van de Statenvertaling vanaf 1639 in de redactie van de liturgische formulieren ging doorwerken, kreeg de tweede doopvraag een variant zónder het dienvolgende en mét een on-

\footnotetext{
72) Rutgers, Het kerkverband, 103 (11 april 1613). Vgl. Evenhuis, Ook dat was Amsterdam I, 237.
}

73) Evenhuis, Ook dat was Amsterdam, 236.

74) Kuyper, De Post-Acta, 158v. Noch in de stukken van de classis Amsterdam (GAA, Classis Amsterdam, inv. nr. 2), noch in de acta van de synode van Noord-Holland is van deze vraag een spoor te vinden (m.n. Reitsma en Van Veen, Acta II, 21-25, 29-31 (vgl. ook 18v)).

75) Trigland, Kerkelycke Geschiedenissen, 664 (curs. Trigland). In het licht van de Amsterdamse kerkenraadsnotulen zal 'ofte' begrepen moeten worden als ofwel: het "in dese Kercke" is een uitleg van het 'alhier' (vgl. De Jong en De Jong, “Van forme naar formulier," 41, waar hier nog een vraagteken bij werd geplaatst).

76) Bijvoorbeeld: versie Dathenus 1566d: Dathenus 1633b; versie Synode 1586: Dathenus 1621a, 1629a, 1633b; Amsterdam: Biblia, dat is [... ] (Amsterdam: Paulus van Ravesteyn, 1624; editie KB 345 G 14; de uit de UB Leiden afkomstige en op google books geplaatste editie heeft de versie Synode 1586), Dathenus 1635a, alsmede idem als 1635a, maar Leyden: David Jansz van Ilpendam (NB: twee van de drie gedrukt in Amsterdam). 
dubbelzinnig alhier: "ende inde Christelijcke Kercke alhier”. ${ }^{77}$ Heeft Trigland aan die nieuwe status quo in 1650 een historisch fundament willen geven?

In de uit 1640 daterende remonstrantse uitgave van de formulieren voor doop en avondmaal ontbreken de doopvragen in hun geheel. Episcopius en Wtenbogaert signaleren volgens de inleiding 'veranderingh' in de redactie van de tweede doopvraag “in verscheyden Exemplaren zedert den jare 1619 ghedruckt". ${ }^{78}$ De Haagse redactie van 1586 is volgens hen vervangen door een formulering die zonder dat zij er overigens zelf enige kwalificatie aan geven gelijk blijkt aan die van Dathenus 1566. Tezamen met het bezwaar tegen het 'daer inne' opvoeden in de derde vraag is "best gevonden ende stichtelijckst, die stipulatie of afeyschinghe van beloften na te laten" en er een vermaning voor in de plaats te stellen. ${ }^{79}$ Uit het remonstrantse formulier zelf blijkt dat de vermaning betrekking heeft op het opvoeden van de dopeling tot een gehoorzaam leven naar Gods geboden. ${ }^{80}$ Hoewel Dathenus 1566 steeds zeldzamer werd en de situatie veel diverser lijkt te zijn geweest dan door hen gesuggereerd, ontbrak voor Episcopius en Wtenbogaert kennelijk een basis om de doopvragen op enigerlei wijze te handhaven.

\section{Conclusies}

In de gereformeerde kerk van Amsterdam zijn in de jaren tien van de 17e eeuw tenminste drie verschillende versies als basis voor de tweede doopvraag gehanteerd: Dathenus 1566, Van der Heyden 1580 en 's-Gravenhage 1586. Gelet op de uiteenlopende citaten in de verslagen van de incidenten op 14 februari en 2 april 1613, zijn er in de praktijk hoogstwaarschijnlijk nog meer geweest, afhankelijk van de wijze waarop de dienstdoende predikant de formulieren gebruikte en voordroeg. ${ }^{81}$ De kerkenraad sanctioneerde de verscheidenheid in formulieredities en was er slechts met moeite toe te bewegen eenheid aan te brengen in de redactie van de vraag. Een en ander maakt het voor ons heden ten dage tot een complexe opgave om de gang van zaken in de genoemde doopdiensten te reconstrueren. Deze verscheidenheid is een illustratie van de veelvuldige klachten op meerdere kerkelijke vergaderingen over het gebrek aan liturgische eenheid. ${ }^{82}$ De Amsterdamse kerkenraad lijkt met deze verschei-

77) Dathenus 1639b. Vgl. De Jong en De Jong, "Van forme tot formulier," 52. Vgl. verder de formulering van de vierde vraag bij de volwassendoop zoals de synode van Dordrecht die in 1619 vaststelt: "alle de articulen der Christelijcke religie, ghelyck die hyer inde christlycke kercke uyt den Woorde Goodts geleert worden" (H.J. Olthuis, De doopspraktijk der Gereformeerde Kerken in Nederland. 1568-1816 (Utrecht, Ruys, 1908) 265).

78) Onderwysinge, "Voor-reden."

79) Onderwysinge, "Voor-reden."

80) Onderwysinge, 6-8, 12-14.

81) Daarnaast kan de diversiteit in edities een rol hebben gespeeld: zie De Jong en De Jong, "Van forme tot formulier," 47-55.

82) We beperken ons hier tot de verzoeken die de synode van Dordrecht bereikten: Kuyper, De Post-Acta, 422 (Gelderland), 430 (Zuid-Holland), 444 (Overijssel); vgl. ook 465. 
denheid in ieder geval geen moeite te hebben gehad.

De berichtgeving over de Amsterdamse doopdiensten is ten aanzien van de tweede doopvraag niet altijd even nauwkeurig geweest. Dat is bij beide partijen het gevolg geweest van een sterke fixatie op het de aanwezigheid van het 'dienvolgende' en de uitleg van het 'hier'. Zowel de formulering bij Dathenus 1566d als die bij Van der Heyden 1580 bevat een 'hier', maar dit geldt niet voor de grote hoeveelheid edities die sinds 1589 verschenen waren en terug gaan op 's-Gravenhage 1586. Het 'hier' was in ieder geval in de verschillende versies van Dathenus multi-interpretabel. Toen echter het 'hier' als in 'hier in deze kerk' in de steeds feller wordende strijd tussen remonstranten en contraremonstranten een sjibbolet van gereformeerde rechtzinnigheid geworden was, kon het in de Haagse variant van 1586 vrij eenvoudig alsnog worden ingevoegd, zoals ook de Amsterdamse wederwaardigheden laten zien. Uiteindelijk verdween zelfs het door de remonstranten voorgestane 'dienvolgende' en bleef het 'hier' over. Nader onderzoek van de verschillende edities uit de eerste decennia na de Dordtse synode zal duidelijk moeten maken hoe deze ontwikkeling precies is verlopen en welke impact de in Amsterdam gemaakte keuzes hierop hebben gehad.

De remonstranten gingen een andere weg. Zij hebben zich geen rekenschap gegeven van de verscheidenheid aan edities die na 's-Gravenhage 1586 en na Dordrecht 1618-19 in omloop bleef. In het bijzonder lijkt de editie van Van der Heyden 1580 hen onbekend te zijn (gebleven). Zij hadden op zich kunnen leven met de versie van 's-Gravenhage 1586, zoals ook uit de reacties van Episcopius en Wtenbogaert blijkt. Nadat echter de remonstranten noodgedwongen een eigen weg waren gegaan, namen zij uiteindelijk een veel radicalere stap. Zij sloten hiermee aan bij een keuze die sommige ruimdenkende gemeenten en predikanten al voor de Dordtse synode gemaakt hadden. Zij schrapten de doopvragen in hun geheel en vervingen ze door een vermaning, in lijn met de verdraagzaamheid die de remonstranten van het begin af aan hoog in het vaandel hadden staan. Het woord vermaning was overigens ook bekend in Datheens formulier. Daar omvatte het echter nadrukkelijk ook de doopvragen. Hoewel niet precies is vast te stellen welke rol de doopincidenten uit 1613 in deze stap hadden, zullen die in de besluitvorming zeker hebben meegespeeld. De beide uitgevers van de remonstrantse formulieren waren er persoonlijk direct bij betrokken en bleven erover publiceren. Zij onderstreepten met het schrappen hun positie: ze wilden zich niet vastleggen op een bepaalde vastomlijnde leer.

Klaas-Willem de Jong is Assistant Professor Church Polity at the Protestant Theological University (PThU, Amsterdam-Groningen) and leader of the project 'The dynamics of the classical reformed liturgy in the Netherlands'.

Email: k.w.de.jong@pthu.nl 
Wouter Kroese, MSc MA is a PhD student at the Protestant Theological University (PThU, Amsterdam) working on the history of the classical reformed baptismal form within the project 'The dynamics of the classical reformed liturgy in the Netherlands'.

E-mail: w.d2.kroese@pthu.nl 